\title{
ANALISIS MAKNA SETIAP PERISTIWA SEJARAH MELALUI PENERAPAN MODEL BERSTRUKTUR
}

\author{
Zafri \\ Jurusan Sejarah Fakultas Ilmu Sosial Universitas Negeri Padang \\ Email: zafriajo@fis.unp.ac.id \\ Hera Hastuti \\ Jurusan Sejarah Fakultas Ilmu Sosial Universitas Negeri Padang
}

\begin{abstract}
Abstrak
Memaknai peristiwa sejarah melalui pembelajaran berstruktur merupakan model baru yang dikembangkan dari teori struktural. Teori struktural sendiri diturunkan dari perspektif filsafat spekulatif, yang meyakini bahwa sejarah memiliki pola-pola dasar yang tetap dan konstan. Pola dasar yang dimaksud yaitu, setiap peristiwa sejarah memiliki proses awal (lahir) peristiwa, proses berkembang, puncak (kejayaan), proses kemunduran, dan hancur (habis). Meski tidak seluruh peristiwa sejarah lengkap memiliki semua pola, adakalanya setelah lahir langsung mencapai puncak kejayaan, dan kemudian tiba-tiba hancur karena suatu peristiwa. Kompleksnya materi sejarah yang diajarkan kepada anak didik, membutuhkan suatu strategi atau model yang tepat untuk meramunya, agar tujuan, nilainilai, dan makna setiap peristiwa sejarah tersampaikan. Artikel ini khusus membahas penerapan model berstruktur dalam pembelajaran sejarah, untuk mencari dan menganalisis makna setiap perubahan dalam peristiwa sejarah.
\end{abstract}

Kata Kunci: Analisis, Struktural, Filsafat Spekulatif

\begin{abstract}
Meaning to play history using structured is a new model developed from structural theory. Structural theory itself comes from the perspective of speculative philosophy, which believes that history has fixed and constant archetypes. The basic pattern referred to is, each play history has an initial process (birth), a process of developing, a peak (glory), a process of decline, and destruction (exhausted). Although not all complete historical events have all the patterns, sometimes after birth immediately reaches the peak of glory, and then suddenly comes back. The complexity of the historical material that is done for students, making the right strategy or model to make it happen, so that the goals, mean values, and meaning of each historical screening are conveyed. This article specifically discusses the application of structured models in history learning, to find and analyze meanings in historical languages.
\end{abstract}

Keywords: Analysis, Structural, Speculative Philosophy

\section{PENDAHULUAN}

Banyak teori dan aplikasi yang sudah dikembangkan oleh peneliti maupun pemerhati pendidikan sejarah, sebagai upaya menjadikan pembelajaran sejarah lebih menarik, lebih memotivasi, hingga lebih bermakna. Namun, yang selalu muncul kepermukaan ketika membahas tentang pembelajaran sejarah adalah sejarah itu membosankan, nihil guna, tanpa makna, bahkan menjadi pelengkap derita para siswa. Menanggapi fenomena pembelajaran sejarah, para sejarawan dan pakar pendidikan sejarah berargumentasi, banyak hal yang menjadi problematika sejarah, mulai dari kurikulum, masalah model pembelajaran, 
strategi pembelajaran, materi pelajaran, permasalahan buku ajar dan buku teks, sampai pada kajian profesionalisme pendidik.

Hamid Hasan dalam Alfian (2007) berpendapat, peserta didik tidak mampu melihat (menganalisis) relevansi materi sejarah dengan kehidupan masa kini, apa lagi masa depan. Hal ini terjadi karena pembelajaran sejarah cenderung hanya memanfaatkan fakta sejarah sebagai materi utama, sehingga setiap peristiwa sejarah terasa kering, tidak menarik, tidak memberi ruang bagi peserta didik untuk belajar menggali makna dari peristiwa sejarah.

Taufik Abdullah melihat persoalan pembelajaran sejarah di tanah air terletak pada strategi pedagogis yang sangat lemah. Penyajian materi sejarah masih berkutat pada pendekatan chronicle sehingga menuntut peserta didik menghafal suatu peristiwa (Abdullah dalam Alfian, 2007:2). Pembelajaran sejarah, tidak membiasakan atau melatih siswa mengartikan dan memaknai suatu peristiwa, untuk memahami dinamika suatu perubahan.

Pelajaran sejarah, menurut Martanto (2009:10) belum mampu meramu peristiwa sejarah dengan pengalaman keseharian dan lingkungan sosial yang dimiliki siswa sebagai bahan pembelajaran di kelas. Padahal Widja (1989:13), sudah menyatakan kekurangcermatan pendidik memilih strategi mengajar, berakibat fatal bagi pencapaian tujuan pengajaran itu sendiri.

Dari pendapat ahli di atas, ada tiga hal yang menjadi permasalahan utama pembelajaran sejarah; 1) Materi pembelajaran sejarah belum distruktur dengan baik; 2) Guru belum mampu meramu materi sejarah agar lebih bermakna; 3) Anak didik belum menerapkan 'belajar dari pengalaman orang terdahulu.'

Model pembelajaran berstruktur hadir sebagai salah jawaban dalam pembenahan materi sejarah agar lebih bermakna dan dekat dengan keseharian siswa. Model pembelajaran berstruktur, menuntun peserta didik berpikir proses, berpikir kritis, berpikir analisis, berpikir tiga dimensi waktu dan menganalisis nilai moral yang terkandung dalam materi pembelajaran sejarah. Selain itu, model pembelajaran berstruktur memberi keleluasaan bagi pendidik mengolah dan menata materi pelajaran, sehingga pendidik dan peserta didik aktif menggali informasi tentang suatu topik pembelajaran sejarah.

\section{PEMBAHASAN}

\section{APA ITU STRUKTUR?}

Sebelum membahas lebih dalam tentang penerapan model berstruktur 
dalam pembelajaran sejarah, maka kita bahas terlebih dahulu tetang struktur. Struktur dalam KBBI berarti, cara sesuatu disusun atau dibangun, dapat juga diartikan sebagai susunan, bangunan, atau sesuatu yang disusun dengan pola tertentu. Struktur kemudian diadopsi dalam kata strukturalisme, yang dalam bahasa Inggris disebut juga dengan structuralism dan struere atau structura dalam bahasa latin berarti, membangun atau bentuk bangunan.

Strukturalisme adalah sebuah paham yang mempercayai bahwa setiap kebudayaan dan masyarakat memiliki struktur yang sama dan konstan. Riset tentang struktur berkembang sejak abad ke XX oleh para ahli humaniora. Model struktural muncul sebagai reaksi terhadap evolusionisme positivis, dengan mengadopsi metode riset struktural yang dihasilkan oleh ilmu pasti, seperti matematika, fisika, kimia dan ilmu lain.

Ferdinand de Saussure (1857 1913), yang digelari sebagai bapak strukturalisme menyatakan bahwa strukturalisme merupakan metode berpikir dalam memahami realitas. Strukturalisme digunakan untuk mempelajari ilmu kemanusiaan yang berpijak pada prinsip linguistik. Saussure meyakini strukturalisme sebagai aliran filsafat yang bertujuan untuk memahami manusia, sejarah, kebudayaan dan hubungan kebudayaan dengan alam, karena strukturalisme menyelidiki pola-pola dasar yang tetap dalam berbagai realitas kehidupan.

\section{MUNGKINKAH SEJARAH BERSTRUKTUR?}

Tujuan strukturalisme yakni mencari struktur terdalam dari realitas yang tampak seolah kacau dan beraneka ragam. Untuk menjawab pertanyaan “mungkinkah sejarah berstruktur?” mari kita analisis melalui ciri-ciri sesuatu yang dapat dilihat strukturnya, yaitu;

1) Sesuatu itu seolah terlihat tidak beraturan hanya dipermukaan saja, akan tetapi sesungguhnya, jika ditelisik lebih mendalam ternyata ia memiliki sebuah mekanisme generatif yang konstan.

2) Mekanisme generatif tersebut selain bersifat konstan, juga terpola, terorganisir, dan ada blok-blok unsur yang dikombinasikan dan dipakai untuk menjelaskan sesuatu yang tampak dipermukaan.

3) Sesuatu dapat dikatakan objektif, apabila peneliti mampu menjaga jarak terhadap penelitian mereka.

4) Strukturalisme seringkali dianggap melampaui humanisme, karena cenderung mengurangi atau mengabaikan peran subjek (peneliti). 
Dari ciri-ciri sesuatu yang dapat distrukturkan di atas, sekarang kita analisis setiap poinnya dalam kajian sejarah,

1. Jabaran peristiwa sejarah seolah tampak kacau, semua masa lalu bisa dijadikan sejarah. Padahal tidak semua kejadian masalalu bisa dijadikan sejarah. Sejarah memiliki hubungan sebab-akibat yang bisa digeneralisasikan.

2. Ketika kita mensejarahi sebuah kebudayaan, hal pertama yang dikaji adalah latar belakang atau awal lahirnya kebudayaan tersebut. Begitupun ketika mengkaji peristiwa sejarah, contohnya peristiwa proklamasi kemerdekaan, selalu bahasan pertamanya adalah latar belakang atau awal peristiwa proklamasi. Maka dapat kita simpulkan sejarah memiliki pola, untuk menjelaskan sebuah peristiwa.

3. Menurut Louis Gottschalk (2008:34), sejarah harus objektif, tidak memihak dan benar, bebas dari pendapat pribadi penelitinya.

4. Sejarah juga harus memiliki eksistensi yang merdeka, lepas dari unsur subjektif penelitinya (sejarawan).

Jabaran di atas telah mengantarkan kita pada asumsi awal bahwa sejarah memiliki struktur yang tetap atau konstan. Analisis kenapa sejarah memiliki struktur atau bisa distrukturkan, kita bahas pada sub berikut.

\section{KENAPA SEJARAH BERSTRUKTUR?}

Strukturalisme, yang dalam kajian filsafat sejarah spekulatif dikenal dengan gerak sejarah, karena gerak sejarah bersifat konstan dan terstruktur. Model pembelajaran berstruktur sendiri dikembangkan dari teori struktural pada perspektif filsafat sejarah spekulatif. Pada hakekatnya filsafat sejarah memiliki dua kajian, yang pertama filsafat sejarah kritis dan yang kedua filsafat sejarah spekulatif. Menyinggung tentang filsafat sejarah spekulatif, sejarawan F.R. Ankersmit (1987: 17) menyatakan bahwa filsafat sejarah spekulatif adalah suatu perenungan filsafati tentang tabiat dan sifat-sifat progres sejarah atau gerak sejarah. Kemudian R.Z. Leirrisa (1996) juga menyatakan filsafat sejarah spekulatif mencari suatu struktur yang tersembunyi tetapi ada dalam proses historis, yang mampu menjelaskan mengapa sejarah berlangsung demikian.

Jabaran tentang teori gerak sejarah, Rustam E. Tamburaka (1999) menyatakan bahwa teori gerak sejarah adalah suatu gerak yang tumbuh dan berkembang secara evolusi, karena menggambarkan peristiwa sejarah masa 
lampau secara kronologis. Urutan secara kronologis merupakan pokok teori untuk menggambarkan gerak sejarah. Gerak sejarah ditandai dengan peristiwa muncul (lahir), berkembang, masa kejayaan, kemunduran dan lenyapnya (hancur) suatu kebudayaan atau kerajaan.

Analisis para sejarawan di atas, kembali menegaskan bahwa setiap peristiwa sejarah memiliki struktur yang konstan; yaitu lahir, berkembang, kejayaan, kemunduran, dan hancur. Meski tidak semua struktur tersebut harus ada dalam setiap peristiwa sejarah, misalnya, ada kebudayaan atau kerajaan yang setelah mencapai puncak kejayaan, langsung hancur. Salah satu contohnya adalah Sejarah Kerajaan Singosari yang mencapai puncak kejayaan pada masa pemerintahan Raja Kertanegara (1268), akan tetapi Singosari langsung mengalami kehancuran, ketika Raja Kertanegara terbunuh dalam pemberontakan yang dilakoni oleh Jayakatwang tahun 1292 M.
Terbunuhnya Raja Kertanegara, serta merta meluluhlantakkan Kerajaan Singosari, dan tak pernah bangkit lagi dengan nama yang sama dalam sejarah.

Berbicara sejarah adalah bicara tentang proses. Proses tersebut dimulai dari proses lahir atau yang lebih kita kenal dengan latar belakang peristiwa, proses berkembang, puncak kejayaan, proses kemunduran, dan kehancurannya (habis).

\section{BAGAIMANA MENERAPKAN MODEL BERSTRUKTUR DALAM PEMBELAJARAN SEJARAH?}

Sejarah adalah peristiwa, sejarah adalah proses, dan sejarah adalah gerak perubahan. Maknanya, yang bukan peristiwa, yang tidak mendeskripsikan proses, dan yang tidak menganalisis perubahan, bukanlah sejarah. Merangkai materi sejarah dengan model berstruktur, langkah awal penerapannya dapat menggunakan tabel gerak perubahan dengan pola dasar pengembangannya dengan mengkaji fakta, konsep, dan prinsip atau kausalitas sejarah. Lebih lengkap dapat dilihat pada tabel berikut,

Tabel 1: Gerak Perubahan Peristiwa Sejarah

\begin{tabular}{|c|c|c|c|}
\hline $\begin{array}{c}\text { Gerak } \\
\text { Perubahan }\end{array}$ & $\begin{array}{c}\text { Fakta } \\
\text { (Who, When, }\end{array}$ & $\begin{array}{c}\text { Konsep } \\
\text { (What) }\end{array}$ & $\begin{array}{c}\text { Prinsip } \\
\text { (Why) }\end{array}$ \\
\hline
\end{tabular}




\begin{tabular}{|c|c|c|c|}
\hline & Where, How) & & \\
\hline Lahir & $\begin{array}{l}\text { Siapa? } \\
\text { Kapan? } \\
\text { Dimana? } \\
\text { Apa yg } \\
\text { dilakukan? }\end{array}$ & $\begin{array}{l}\text { Apa yang } \\
\text { terjadi? }\end{array}$ & $\begin{array}{l}\text { Apa penyebab } \\
\text { lahirnya? }\end{array}$ \\
\hline Berkembang & $\begin{array}{l}\text { Siapa? } \\
\text { Kapan? } \\
\text { Dimana? } \\
\text { Apa yg } \\
\text { dilakukan? }\end{array}$ & $\begin{array}{l}\text { Apa yang } \\
\text { berkembang? }\end{array}$ & $\begin{array}{l}\text { Apa penyebab } \\
\text { berkembang? }\end{array}$ \\
\hline $\begin{array}{l}\text { Puncak } \\
\text { Kejayaan }\end{array}$ & $\begin{array}{l}\text { Siapa? } \\
\text { Kapan? } \\
\text { Dimana? } \\
\text { Apa yg } \\
\text { dilakukan? }\end{array}$ & $\begin{array}{l}\text { Apa yang } \\
\text { berjaya? }\end{array}$ & $\begin{array}{l}\text { Apa penyebab } \\
\text { kejayaan? }\end{array}$ \\
\hline Mundur & $\begin{array}{l}\text { Siapa? } \\
\text { Kapan? } \\
\text { Dimana? } \\
\text { Apa yg } \\
\text { dilakukan? }\end{array}$ & $\begin{array}{l}\text { Apa yang } \\
\text { mundur? }\end{array}$ & $\begin{array}{l}\text { Apa penyebab } \\
\text { mundur? }\end{array}$ \\
\hline $\begin{array}{l}\text { Hancur/ } \\
\text { Habis }\end{array}$ & $\begin{array}{l}\text { Siapa? } \\
\text { Kapan? } \\
\text { Dimana? } \\
\text { Apa yg } \\
\text { dilakukan? }\end{array}$ & $\begin{array}{l}\text { Apa yang } \\
\text { hancur? }\end{array}$ & $\begin{array}{l}\text { Apa penyebab } \\
\text { hancur? }\end{array}$ \\
\hline
\end{tabular}

Implikasi fakta, konsep, dan prinsip dalam struktur gerak perubahan sejarah merupakan aplikasi $5 \mathrm{~W} 1 \mathrm{H}$ (What, When, Who, Where, Why, dan How) dalam setiap kajian peristiwa sejarah. Fakta sejarah disusun dari setiap peristiwa sejarah melalui analisis who, when, where, dan how. Bukanlah menjadi sebuah fakta sejarah jika dalam peristiwa sejarah tidak diketahui kapan waktu (when) peristiwa sejarah itu terjadi, atau tidak diketahui siapa (who) tokoh atau orang yang terlibat dalam peristiwa sejarah. Hakekatnya sejarah hanya dan selalu mengkaji dan mensejarahi manusia. Begitupun ketika berbicara konsep sejarah, konsep disusun dari pertanyaan apa (what) yang terjadi. Berbeda dengan fakta sejarah, konsep sejarah bias akan waktu dan tempat, konsep hadir untuk menyederhanakan setiap peristiwa yang kompleks, dan 
mengurai setiap peristiwa sejarah yang rumit. Kemudian kausalitas atau prinsip sejarah merupakan 'roh' dari sejarah itu sendiri, sejarah selalu berbicara sebab-akibat, atau akibat-sebab yang landasannya berpikirnya adalah kenapa (why) peristiwa sejarah itu terjadi. Hakekatnya sejarah mengkaji dan menganalisis sebab terjadinya peristiwa, sehingga cara pikir dan sudut pandang dalam kajian sejarah adalah induktif, yaitu mengkaji akibat untuk mengetahui sebab.

Sekarang mari kita aplikasi model berstruktur dalam salah satu contoh peristiwa sejarah, yaitu Sejarah Kerajaan Kutai. 
Tabel 2. Gerak Perubahan Sejarah Kerajaan Kutai

\begin{tabular}{|c|c|c|c|}
\hline $\begin{array}{l}\text { Gerak } \\
\text { Sejarah }\end{array}$ & $\begin{array}{l}\text { Fakta } \\
\text { (Siapa, Bagimana, } \\
\text { Kapan, Di mana) }\end{array}$ & $\begin{array}{l}\text { Konsep } \\
\text { (Apa) }\end{array}$ & $\begin{array}{l}\text { Prinsip; Sebab - akibat } \\
\text { (Kenapa) }\end{array}$ \\
\hline Lahir & $\begin{array}{l}\text { Aswawarman } \\
\text { mendirikan } \\
\text { Kerajaan Kutai } \\
\text { pada awal abad } \\
\text { ke V M di Kutai } \\
\text { Kalimantan } \\
\text { Timur. }\end{array}$ & $\begin{array}{l}\text { Kerajaan } \\
\text { Vrastyasto } \\
\text { ma } \\
\text { Wangsakar } \\
\text { ta } \\
\text { Yupa } \\
\text { Kasta } \\
\text { Hindu }\end{array}$ & $\begin{array}{l}\checkmark \text { Meski agama Hindu masuk pada saat } \\
\text { Kudungga menjadi pemimpin, akan } \\
\text { tetapi Aswawarman dianggap sebagai } \\
\text { raja pertama Kerajaan Kutai, karena } \\
\text { Prasasti Yupa menyebutkan } \\
\text { Aswawarman sebagai Wangsakerta, } \\
\text { yaitu pendiri Keluarga Kerajaan. } \\
\checkmark \text { Vrastyastoma (upaca penyucian) } \\
\text { dilaksanakan di Kerajaan Kutai, } \\
\text { sehingga menjadikan keluarga kerajaan } \\
\text { seluruhnya beragama Hindu. } \\
\checkmark \text { Aswawarman resmi memakai gelar raja } \\
\text { dan menetapkan agama Hindu sebagai } \\
\text { agama kerajaan. } \\
\checkmark \text { Abad ke IV dan V M, agama Hindu } \\
\text { mengalami perkembangan pesat di } \\
\text { India, sehingga menyebar ke wiayah } \\
\text { lain, termasuk ke Nusantara. } \\
\checkmark \text { Munculnya Kerajaan Kutai tidak terlepas } \\
\text { dari situasi jalur perdagangan } \\
\text { sebelumnya yang sudah tidak aman lagi, } \\
\text { sehingga jalur perdagangan berubah } \\
\text { menyusuri daerah Kalimantan dan } \\
\text { menjadikan daerah ini menjadi ramai. } \\
\checkmark \text { Nama Kutai sendiri diambil dari nama } \\
\text { kota di mana ditemukannya prasasti } \\
\text { yang menunjukkan keberadaan kerajaan } \\
\text { tersebut, yaitu di kota Kutai, } \\
\text { Kalimantan Timur. }\end{array}$ \\
\hline $\begin{array}{l}\text { Kejayaa } \\
n\end{array}$ & $\begin{array}{l}\text { Kerajaan Kutai } \\
\text { mencapai puncak } \\
\text { kejayaan pada } \\
\text { masa } \\
\text { pemerintahan } \\
\text { Raja Mulawarman } \\
\text { pada abad }\end{array}$ & $\begin{array}{l}\text { Brahmana } \\
\text { Wapakesw } \\
\text { ara }\end{array}$ & $\begin{array}{l}\checkmark \text { Mulawarman merupakan raja yang } \\
\text { cakap dalam mengatur } \\
\text { pemerintahannya, selain itu ia juga raja } \\
\text { yang dhermawan. } \\
\checkmark \text { Hampir seluruh wilayah Kalimantan } \\
\text { Timur dikuasai oleh Kerajaan Kutai. } \\
\checkmark \text { Prasasti Yupa dibuat pada masa } \\
\text { pemerintahan Raja Mulawarman oleh }\end{array}$ \\
\hline
\end{tabular}




\begin{tabular}{|c|c|c|c|}
\hline & & & $\begin{array}{l}\text { kaum Brahmana sebagai penghormatan } \\
\text { terhadap raja atas segala kebaikannya. } \\
\checkmark \text { Didirikan Wapakeswara, tempat suci } \\
\text { untuk penyajian. }\end{array}$ \\
\hline Hancur & $\begin{array}{l}\text { Kerajaan Kutai } \\
\text { mengalami } \\
\text { kehancuran pada } \\
\text { masa } \\
\text { pemerintahan } \\
\text { Raja Dharma } \\
\text { Setia pada Abad } \\
\text { ke XIV M }\end{array}$ & $\begin{array}{l}\text { Perang } \\
\text { Friksi }\end{array}$ & $\begin{array}{l}\checkmark \text { Raja Dharma Setia tewas dalam perang } \\
\text { melawan Aji Pangeran Anom dari Kutai } \\
\text { Kertanegara. } \\
\checkmark \text { Kutai dan Kutai Kertanegara merupakan } \\
\text { dua kerajaan yang berbeda aliran, akan } \\
\text { tetapi sama-sama terletak di daerah } \\
\text { Sungai Mahakam } \\
\checkmark \text { Kerajaan Kutai Kertanegara berdiri abad } \\
\text { ke XIII M dilokasi Kerajaan Kutai lama, } \\
\text { sehingga menimbulkan friksi diantara } \\
\text { keduanya. }\end{array}$ \\
\hline
\end{tabular}

Dari gerak sejarah Kerajaan Kutai tersebut, terlihat setelah proses lahir atau berdirinya kerajaan, kemudian puncak kejayaan, dan hancur, tidak ada proses berkembang dan proses kemundurannya. Hal ini lumrah terjadi, karena sejarah atau peristiwa sejarah direkontruksi dari sumber dan bukti yang ada (yang ditemukan). Pola gerak sejarah Kerajaan Kutai bisa saja berubah (lengkap), jika dikemudian hari ditemukan lagi bukti-bukti yang mendukung terjadinya setiap perubahan tersebut.

\section{MODEL BERSTRUKTUR UNTUK KEBERMAKNAAN PEMBELAJARAN SEJARAH}

Penerapan model berstruktur untuk kebermaknaan pembelajaran sejarah dapat dilihat dari penerapan,
Louis Gottschalk (1985) menyatakan fakta sebagai suatu unsur yang dapat dijabarkan secara langsung ataupun tidak langsung dari dokumen sejarah yang dianggap kredibel setelah melewati proses pengujian dalam metode sejarah. Fakta disusun dan direkontruksi oleh sejarawan atau peneliti sejarah dari bukti-bukti yang ada (ditemukan) (Ankersmit, 1987:100).

Unsur pembangun dari fakta peristiwa sejarah memiliki tokoh (manusianya) tahun, tempat, dan peristiwa. Fakta mengajarkan peserta didik untuk berpikir lebih konkrit, bahwa sebuah peristiwa, dikatakan sebagai peristiwa sejarah, harus memiliki unsur yang lengkap yaitu man (manusia), space (tempat), time (waktu).

Fakta 


\section{Konsep}

Mehlinger dalam Waney (1989:68) mengungkapkan konsep merupakan gambaran dalam pikiran tentang sejumlah fenomena yang mempunyai ciri yang sama. Bagi Ratna W. Dahar (1989:79) konsep merupakan batu-batu pembangunan (building block) dalam berpikir. Waney (1989: 68) kemudian menegaskan bahwa konsep mempermudah komunikasi, karena hanya dengan beberapa kata tertentu kita dapat menyampaikan banyak hal yang dapat segera dipahami oleh orang lain tanpa penjelasan yang lebih rinci. Misalnya, orang akan segera mengerti ketika kita berbicara tentang, demonstrasi, perang, kemerdekaan, revolusi, dan sebagainya.

Peran konsep dalam proses belajar mengajar sangat penting, tanpa adanya konsep maka proses pembelajaran akan terhambat dan memakan waktu yang sangat lama. Materi sejarah yang membahas masa lalu, tentunya tidak dapat diputar kembali dan disaksikan secara langsung. Ditegaskan oleh Burston (1972:24 dalam I Gde Widja 1989:22), “we cannot present historical fact to our class for their direct inspection and examination", kita tidak mungkin membawakan fakta-fakta sejarah ke dalam kelas untuk diamati dan diperiksa secara langsung. Disini konsep memainkan perannya sebagai penghubung peristiwa masa lampau kemasa sekarang, karena salah satu karakteristik konsep adalah lintas waktu dan tempat.

$$
\begin{aligned}
& \text { Abizar (2001:91), berkesimpulan ada } \\
& \text { tiga kemampuan pokok yang bisa kita } \\
& \text { miliki atau latih berkenaan dengan } \\
& \text { konsep, yaitu: }
\end{aligned}
$$

a) kemampuan mengingat (remember), berhubungan dengan defenisi konsep atau sampelsampelnya.

b) kemampuan mengaplikasikan (use) konsep terhadap kasus-kasus melalui penalaran deduktif.

c) kemampuan menemukan (find), melalui penalaran induktif.

\section{Prinsip}

Prinsip atau yang sering disebut juga dengan kausalitas (hubungan sebab akibat) menurut F.R Ankersmith (1987:192) menjelaskan tentang prosesproses perubahan dalam sejarah. Kuntowijoyo (1995:26) memandang prinsip kausalitas dalam pembelajaran sejarah merupakan salah satu guna belajar sejarah. Prinsip membawa seseorang untuk tidak berpikir monokausal, sejarah harus berpikir plurikausal, dimana yang menjadi penyebab dari suatu peristiwa sejarah adalah banyak, sehingga sejarah melihat segala sesuatu mempunyai banyak segi. Oleh karena itu dengan melihat prinsip 
kausalitas, orang berpikir berdasarkan perkembangan dan harus mempertimbangkan masa lalu untuk membicarakan masa kini dan membahas masa kini untuk memprediksi masa depan.

Oemar Hamalik

(2002:170)

menjelaskan, suatu prinsip menyatakan hubungan relationship antara peristiwa sehingga kita dapat (1) membuat perkiraan konsekuensi-konsekuensi, (2) menjelaskan peristiwa atau kejadiankejadian, (3) menunjukkan sebabsebab, (4) mengontrol situasi dan, (5) memecahkan masalah.

Tiga Dimensi Waktu (Memaknai Sejarah)

Sejarah sebagai aktualitas adalah berupa peristiwa, kejadian dan perubahan-perubahan yang terjadi pada masa lalu dalam masa cukup panjang. Memahami peristiwa masa lalu yang beragama, dimensi waktu merupakan sesuatu yang sangat esensial, karena waktu adalah penuntun untuk melakukan pembagian (pembabakan) suatu peristiwa.

Sartono Kartodirjo menegaskan bahwa proses perkembangan meliputi tiga zaman. Segala yang bereksistensi masa kini adalah produk dari perkembangan masa lampau, keadaan masa kini menentukan masa depan. Tepatlah dikatakan bahwa dalam masa kini tersimpan masa lampau dan di dalam masa depan tersimpan masa kini.

Melalui penerapan tiga dimensi waktu (masa lalu, masa kini, masa depan), pembelajaran sejarah tidak lagi diartikan sebagai pelajaran untuk masa lampau, lebih dari itu, sejarah harus dipandang sebagai sesuatu yang bermanfaat untuk masa sekarang dan masa yang akan datang. Materi sejarah masa lampau adalah alat untuk menerangkan kejadian masa sekarang, dan memiliki daya untuk melakukan peramalan atau prediksi masa yang akan datang.

Contoh yang paling gamblang yaitu, ketika Negara Singapura yang dimasa lalu dihuni oleh mayoritas Bangsa Melayu, bahkan pemimpin pertamanya adalah orang Melayu. Akan tetapi, ketika ia membuka kesempatan yang sebesarbesarnya kepada Cina untuk berinvestasi, membangun dan mengelola negaranya. Maka saat ini kita lihat yang mengusai Negara Singapura adalah Cina, masyarakat Melayu terpinggir, bahkan Singapura dikatakan sebagai negara Cina kedua. Dari peristiwa sejarah ini, kita bisa memprediksi apa yang akan terjadi terhadap Negara Indonesia dimasa depan, karena saat ini pemerintah Indonesia juga memberi peluang yang sebesar-besarnya bagi Cina untuk berinvestasi, membangun infrastruktur bahkan terjadi 'penyerbuan' tenaga kerja Cina ke Indonesia dalam 
jumlah yang sangat besar. Maka masa depan Indonesia dapat kita prediksikan akan bernasib sama dengan Singapura, masyarakat pribumi terpinggirkan, dan Cina yang jadi penguasa.

\section{Efektivitas Pembelajaran Sejarah}

Efektivitas pembelajaran, khususnya pembelajaran sejarah menjadi salah satu permasalahan utama dalam proses pendidikan. Pembelajaran sejarah yang memuat banyak materi seolah dipaksakan kepada peserta didik untuk dapat menguasai keseluruhan materi. Bahkan terkadang mengabaikan kebermaknaan pembelajaran sejarah itu sendiri pada diri peserta didik. Hakekatnya suatu materi pembelajaran diajarkan secara formal di sekolah tentunya memiliki tujuan tertentu yang harus dicapai.

Model pembelajaran berstruktur mengcover materi pembelajaran sejarah yang cenderung berupa uraian dan deskripsi yang kurang terarah menjadi berpola. Sering kali kita temukan pada buku teks pembelajaran sejarah, tidak bisa dikenali mana sebab, dan mana akibat suatu peristiwa sejarah. Model berstruktur memudahkan peserta didik menganalisis kausalitas peristiwa demi peristiwa sejarah.

Dari bahasan keunggulan penerapan model berstruktur di atas dapat kita simpulkan,
1) Mampu melatih berpikir kritis, karena setiap konsep harus diterangkan dengan fakta atau bukti.

2) Melatih berpikir analisis, karena melalui pengajaran konsep harus dilakukan analisis hubungan antara sebab dan akibat (eksplanasi).

3) Mampu memahami peristiwa yang terjadi sekarang, baik dari segi karakter utamanya maupun dari segi proses gerak perubahannya.

4) Mampu memprediksi masa depan berdasarkan hukum-hukum pola gerak perubahan.

5) Menemukan nilai-nilai yang terkandung dalam peristiwa sejarah untuk meningkatkan rasa nasionalisme dan semangat kebangsaan.

\section{KONKLUSI}

Salah satu aliran dalam filsafat sejarah adalah filsafat sejarah spekulatif. Aliran filsafat ini meyakini bahwa sejarah memiliki pola tertentu dan berulang.

\section{DAFTAR PUSTAKA}

A. Sobana HS. Metode Penelitian Sejarah (Metode Sejarah). Materi penyuluhan dalam "Workshop Penelitian dan Pengembangan Kebudayaan; Penulisan Karya Ilmiah dan Perekaman Data". Bandung, 1214 Februari 2008.

Achmad Munib. 2009. Pengantar Ilmu Pendidikan. Semarang: Unnes Press 
Bambang Purwanto. 2006. Gagalnya Historiografi Indonesiasentris?!. Yogyakarta: Ombak

Belth, Marc.(1977) The Process Of Thinking.New York: David Mc Kay Company

Boyi Anggara dan Adam AW. 2005. Menggugat Historiografi Indonesia. Yogyakarta. Ombak

Boyi Anggara. 2007. 'Pembelajaran Sejarah yang Berorientasi pada Masalah- Masalah Sosial Kontemporer'. Makalah. Disampaikan dalam Seminar Nasional Ikatan Himpunan Mahasiswa Sejarah Se-Indonesia (IKAHIMSI). Universitas Negeri Semarang, Semarang, 16 April 2007

Charles Issawi. 1955. Filsafat Islam Tentang Sejarah; Pilihan dari Muqaddimah karangan Ibn Khaldun dari Tunis (1332-1406). London: American University of Beirut.

Committee on Historigraphy. c. 1954. The Social Sciences in Historical Study. New York: Social Science Research Council.

Costa, Arthur L.,(ed.) Developing Minds, A Resource Book for Teaching Thinking. Virginia: ASCD

Dadang Supardan. 2008. Pengantar Ilmu Sosial; Sebuah Kajian Pendekatan Struktural. Jakarta: Bumi Aksara.

De Bono, Edward. (1990). Berpikir Lateral, alih Bahasa oleh Budi. Jakarta: Binarupa Aksara.

Departemen Pendidikan Nasional. 2005. Ilmu Pengetahuan Sosial-Sejarah jilid 3. Jakarta: Direktorat Jendral Pendidikan Dasar dan Menengah.
Didin Wahidin. Makalah disajikan dalam seminar mahasiswa FKIP Uninus 18 Juni 1998.

Dirmawa, Dikti. (1996). Buku Peserta Pelatihan Pembimbing Kelompok Diskusi Mahasiswa (OPPEK- TIPE B). Dikti Jakarta.

E. Mulyasa. 2007. Kurikulum Tingkat Satuan Pendidikan. Bandung: PT Remaja Rosda Karya.

F.R. Ankersmit. 1987. Refleksi tentang Sejarah; Pendapat-pendapat Modern tentang Filsafat Sejarah (terjemahan Dick Hartoko dari Denken over geschiedenis; een overzicht van moderne geschiedfilosofosche opvattingen). Jakarta: Gramedia.

G.J. Renier. 1997. Metode dan Manfaat Ilmu Sejarah. Terj. Muin Umar. Yogyakarta: Pustaka Pelajar.

Gega, Peter C., (1977) Science in elementary education. New York : John Wiley And Sons Inc.

Hamid Hasan. 2007. 'Kurikulum Pendidikan Sejarah Berbasis Kompetensi'. Makalah. Disampaikan dalam Seminar Nasional Ikatan Himpunan Mahasiswa Sejarah SeIndonesia (IKAHIMSI). Universitas Negeri Semarang, Semarang, 16 April 2007

Hariyono. 1995. Mempelajari Sejarah Secara Efektif. Jakarta : Pustaka Jaya

Harsja W. Bachtiar, dkk. 1983. Sejarah Lisan. Jakarta: Arsip Nasional RI.

Helius Syamsuddin. 2007. Metodologi Sejarah. Yogyakarta: Yayasan Ombak Indonesia

Hugiono \& PK. Poerwantana. 1992. Pengantar Ilmu Sejarah. Jakarta: Rineka Cipta. 
I Gde Widja. 1989. Dasar - Dasar Pengembangan Strategi Serta Metode Pengajaran Sejarah. Jakarta : Depdikbud

Jujun Suriasumantri. 1985. Filsafat Ilmu; Sebuah Pengantar Populer. Jakarta: Sinar Harapan.

Kuntowijoyo. 1994. Metodologi Sejarah. Yogyakarta: Tiara Wacana.

Kuntowijoyo. 1995. Ilmu Sejarah. Yogyakarta.

Louis Gottschalk. 1969. Mengerti Sejarah. Jakarta: UI Press.

M Nursam, dkk (ed). 2008. Sejarah yang Memihak : Mengenang Sartono Kartodirdjo. Yogyakarta : Ombak

Magdalia Alfian. 2007. 'Pendidikan Sejarah dan Permasalahan yang Dihadapi'. Makalah. Disampaikan dalam Seminar Nasional Ikatan Himpunan Mahasiswa Sejarah SeIndonesia (IKAHIMSI). Universitas Negeri Semarang, Semarang, 16 April 2007

MC. Rickleff. 2004. Sejarah Indonesia Modern. Monash University.

MS. Basri. 2006. Metodologi Penelitian Sejarah (Pendekatan, Teori dan Praktik).

Mumuh Muhsin Z. 2007. Filsafat Sejarah Kritik (bahan ajar untuk mata kuliah Filsafat Sejarah I). Jurusan Sejarah Fakultas Sastra Universitas Padjadjaran Jatinangor.

Nickerson, Raymond S., (1985) The Teaching of Thinking. New Jersey: Lawrence Erlbaum

R. Moh. Ali. 1961. Pengantar Ilmu Sejarah Indonesia. Jakarta: LkiS.

Raths, Louis E., et.al. (1986) Teaching for thinking (2'nd ed.). New York:
Teacher College Columbia University.

Restu Gunawan (ed). 1998. Simposium Pengajaran Sejarah (kumpulan makalah diskusi). Jakarta: Depdikbud

S.K Kochar. 2008. Pembelajaran Sejarah. Jakarta : Grasindo

Sam Wineburg. 2006. Berpikir Historis. Jakarta: Yayasan Obor Indonesia.

Sartono Kartodirdjo. 1982. Pemikiran dan Perkembangan Historiografi Indonesia; Suatu Alternatif. Jakarta: Gramedia.

.1993. Pendekatan Ilmu Sosial Dalam Metodologi Sejarah. Jakarta: Gramedia Pustaka Utama.

- Lembaran Sejarah.

Sudaryanto, Kajian Kritis tentang Permasalahan Sekitar Pembelajaran Kemampuan Berpikir Kritis Selasa, 26 Agustus 2008 12:50.

Umar Tirtarahardja dan S.L. La Sulo. 2005. Pengantar Pendidikan. Jakarta: Rineka Cipta. 